UDC 539.2

O. Chulkin, PhD, Assoc. Prof.,

V. Kravchenko, DSc, Prof.,

V. Zotyeyev, PhD, Assoc. Prof.,

O. Zotyeyev

Odessa National Polytechnic University, 1 Shevchenko Ave., Odessa, Ukraine, 65044; e-mail: zoteevoleg@i.ua

\title{
SRUCTURE AND STABILITY OF SOLID SOLUTIONS CRYSTAL LATTICE BASED ON ZIRCONIUM DIOXIDE
}

\begin{abstract}
О.О. Чулкін, В.П. Кравченко, В.О. Зотєєв, О.Е. Зотєєв. Структура та стабільність кристалічної гратки твердих розчинів на основі двоокису цирконію. Метою роботи був розгляд питань, пов'язаних з стабільністю плівки двоокису цирконію, яка утворюється на поверхні твелу при експлуатації ядерного палива. Дослідження проводились для вивчення можливості зменшення радіоактивності теплоносія першого контуру, яка визначається станом герметичності оболонок твелів. Цілісність оболонок визначається рядом факторів, одним з яких є стабільність плівки двоокису цирконію. В цій плівці можуть проходити фазові перетворення, які мають основою сумісну дію температури, тиску та радіації. Процес корозії в умовах першого контуру включає окісну та радіаційну корозію. Окісна корозія $є$ найбільш важливою, а ії швидкість зростає в умовах радіації. Ціллю рентгенографічного дослідження твердих розчинів на основі діоксиду цирконію було отримання інформації стосовно їх структури в залежності від різних домішок іонів-стабілізаторів. Крім того були проведені експерименти з різними зразками які були відпалені при температурі $950{ }^{\circ} \mathrm{C}(1223 \mathrm{~K})$. Рентгенографічні експерименти були проведені на діфрактометрі ДРОН-3,0 в випромінені $\mathrm{K}_{\alpha} \mathrm{Fe}$ $(\lambda=0,194 \mathrm{~nm})$. Експериментальні результати довели, що внесення стабілізуючих іонів Са, Y, $\mathrm{Nd}$, Sc ( в різних молярних концентраціях) в твердий розчин діоксиду цирконію призводить до стабілізації кубічної фази. Також наведені результати по перерозподілу інтенсивності максимумів піків в усіх зразках, які були відпалені при температурі 1223 К, яка наближена до температури фазового перетворення від моноклінної структури в тетрагональну (1370 К) в чистому діоксиді цирконію. Це може бути доказом того, що іони-стабілізатори намагаються зайняти спеціальні вузли в матричній кристалічній гратці. В той же час , це не призводить до суттєвих змін параметрів кристалічної гратки, і внаслідок цього об’єм елементарної комірки майже не змінюється. Це означає, що тверди розчини на основі діоксиду цирконію, які мають кубічну фазу, можуть використовуватись як захисні покриття.

Ключові слова: кераміка, діоксид цирконію, рентгеноструктурний аналіз, іон-стабілізатор
\end{abstract}

O. Chulkin, V. Kravchenko, V. Zotyeyev, O. Zotyeyev. Structure and stability of solid solutions crystal lattice based on zirconium dioxide. The goal of research is the study of problems, which are connected with stability of thin film of zirconium dioxide on the surface of fuel rod during operation. This work has been carried out to investigate the possibility of coolant radioactivity reduction, which depends on the hermetic of fuel rod shell. The integrity of this shell depends on many factors, the main one of which is the stability of zirconium dioxide film. There are some kind of phase transitions in this film, which are based on the integral influence of temperature, pressure and radiation. The process of corrosion includes - oxidative and radioactive corrosion. Oxidative corrosion plays the leading role among them and its speed can increase with the presence of radioactive one. The purpose of roentgen-graphic studies of solid solutions based on zirconium dioxide was an obtaining of information regarding the structure of these compounds in conjunction with different additives of ion stabilizers. At the same time, experiments with different samples subjected to annealing at temperature of $950{ }^{\circ} \mathrm{C}$ during different periods were done. Roentgen studies were carried out on the X-ray diffractometer DRON-3.0 in the emission of $K_{\alpha} \mathrm{Fe}(\lambda=0.194 \mathrm{~nm})$. Experimental results show that an addition of stabilizing ions (in certain molar concentrations) $\mathrm{Ca}, \mathrm{Y}, \mathrm{Nd}$, Sc into the solid solution of zirconium dioxide will lead to the stabilization of cubic phase. In addition, it draws an attention the redistribution of peaks intensity in all researched systems subjected to the annealing at temperature $1223 \mathrm{~K}$ that is close to the temperature of phase transformation from monoclinic structure into tetragonal $(1370 \mathrm{~K})$ in the pure zirconium dioxide. This can be evidence of stabilizing ion streamlining at the special nodes of crystalline lattice of the matrix grid. However, it doesn't lead to the significant change of crystalline lattice parameters and as a result the specific volume of unit cell remains almost without change. It means that solid solutions based on zirconium dioxide that have stabilized cubic phase can be used as protective coatings.

Keywords: zirconium dioxide, X-ray structural analysis, ion stabilizer

Introduction. The purpose of the work was a study of the problem with stability of zirconium dioxide film that appears on the surface of fuel rod (FR) during exploitation of the fuel assembly. The possibilities how to reduce the radioactivity of coolant in the first circuit has been studied. It is known, that radiation situation on the nuclear power plant (NPP) depends on the radioactivity of the coolant. Radioactivity is substantially defined by the condition of second level physical protection - FR shell tightness. During the exploitation, shell tightness is determined by multiple factors, one of those is the stability of zirconium dioxide $\left(\mathrm{ZrO}_{2)}\right.$ film on it surface. Phase transformations can occur in this film that are affected both by temperature, pressure and radiation exposure.

\section{DOI: 10.15276/opu.3.59.2019.08}

(C) 2019 The Authors. This is an open access article under the CC BY license (http://creativecommons.org/licenses/by/4.0/). 
Analysis of the problem. Coolant is an aggressive environment, especially at high temperatures in the condition of intense exposure. This leads to the accelerated corrosion of construction materials. The process of corrosion includes the oxidative corrosion (when oxygen is present) and radioactive corrosion (in the radiation field). Oxidative corrosion plays the leading role among them and its speed can increase with the presence of radioactive one. The speed of corrosion of the construction materials is influenced by the duration of exposure, working temperature, composition of coolant and additives, as well as exposure characteristics, in particular spectrum of neutrons. During the combined influence of corrosive environment and cyclic thermal load it is observed a combination of corrosive and thermal weakness cracking of reactor's construction materials.

Besides the influence of thermal and mechanical loads, construction materials are subjected to the intense exposure, which can result into change of the phase, thermal and mechanical properties. Exposure effect on the FR shell material properties comes down to the three main corrosion acceleration factors:

1. Water and solutions radiolysis.

2. Destruction of thin protective film on the surface of metal.

3. Influence on the corrosion speed of physical and mechanical changes of metal and alloy properties due to radiation.

A thin film, based on zirconium dioxide with micron thickness $(5-15 \mathrm{mcm})$ is created on the surface of HE, washed with coolant, and protects a zirconium alloy underneath it from the corrosive influence of coolant. Change of the film properties due to temperature changes and accumulated fluence, leads to its cracking, which means that coolant will access the main material of FR shell. As a result, corrosion process starts, micro cracks will appear that later will turn into macro cracks. Finally, this can lead to the destruction of FR shell and allow the radioactivity to enter the first circuit. Shell corrosion process during operation depends on many factors characterizing the shell (composition, structure, surface quality etc.) and coolant (speed, composition, thermodynamic parameters) as well as operational conditions. Each FR of WWER-1000 is dispose in the cells of spacer grids, which placed with equal step at the all height of FA (fuel assembly). Shell has three touch points located at $120^{\circ}$. Due to vibration of FR in the coolant flow, wear of shell can occur due to periodic shifting against the touch points. This wear is a fretting corrosion, because it depends on the electro - chemical characteristics of the shell and spacer grid materials and the parameters of coolant. It has been exactly determined that the tension of FR in the cell prevents fretting corrosion and presence of gaps contributes its development. During the calculation of FR shell resource a particular difficulty makes consideration of the effect done both by corrosion and neutron exposure on the film that has been formed on the surface of zirconium alloy.

Zirconium dioxide is a material with monoclinic structure, but during operation the transition into tetragonal type of lattice can happen that is accompanied with change in the specific volume of the single cell almost on $10 \ldots 13 \%$ [1]. Particularly this reduction of volume is one of the reasons of film cracking. At the same time it is known that an addition of the rare earth element oxides $6 . . .10 \%$ mole into the $\mathrm{ZrO}_{2}$ leads to the stabilization of cubic type of the lattice that is not changing under the influence of exposure [2]. In addition, it is known that the speed of film increment changes during campaign Solid solutions based on zirconium dioxide draw big attention due to their unique physical properties [3]. They withstand very well high temperatures . Different systems based on zirconium dioxide are used as coatings, resistant in the destructive environment during normal operation [4]. In normal conditions, pure zirconium dioxide $\left(\mathrm{ZrO}_{2}\right)$ has monoclinic structure with the following lattice parameters: $a=0.5169 \pm 0.0008 \mathrm{~nm}, b=0.5232 \pm 0.0008 \mathrm{~nm}, c=0.5341 \pm 0.0008 \mathrm{~nm}, \beta=99^{\circ} 15^{\prime} \pm 10^{\prime}$.

It is revealed that there are seven close neighbors in the structure a zirconium atom. The oxygen atoms located at the distances from 0.204 to $0.226 \mathrm{~nm}$ and the next nearest oxygen atoms located at the distance of $0.377 \mathrm{~nm}$. It means that coordination value is equal to seven. With increasing temperature up to $1370 \mathrm{~K}$ zirconium dioxide is subjected to transformation. As a result, a tetragonal crystalline lattice is being formed [5]. With the further increase of temperature up to $2570 \mathrm{~K}$, zirconium dioxide is subjected to one more phase transition, as a 
result a cubic lattice of $\mathrm{CaF}_{2}$ type with lattice constant $a=0.508 \mathrm{~nm}$ is being formed [6,7]. When the film increment of zirconium dioxide on the surface of FR exceeds $10 \mathrm{mcm}$ it takes place its loosening. The film may crumble and surface of FR coarsens. This condition is typical for a nodal corrosion. In the absence of technological regulation requirements for the manufacturing of FR shells, in the basic operational mode, oxidation is frontal. Thickness of the film does not exceed $20 \mathrm{mcm}$ during the operation time up to 4 years.

\section{Materials and experimental method}

The purpose of roentgen-graphic studies of solid solutions based on zirconium dioxide was an obtaining of information about the structure of these compounds in conjunction with different additives of ion-stabilizer. At the same time, experiments with different samples subjected to annealing at temperature of $950{ }^{\circ} \mathrm{C}$ during different periods were done.

Roentgen studies were carried out on the roentgen diffractometer DRON-3.0 in the emission ( $\mathrm{Cu} \mathrm{K} \mathrm{K}_{\alpha}$ alpha), located in the Institute of Metal Physic of National Academy of Science of Ukraine. The results of some experiments are introduced below.

\section{Results of X-ray experiments}

Experimental results on the Fig. 1 - Fig. 7 show that an addition of stabilizing ions (in certain molar concentrations) $\mathrm{Ca}, \mathrm{Y}, \mathrm{Nd}$, Sc into the solid solution of zirconium dioxide will lead to the stabilization of cubic phase.

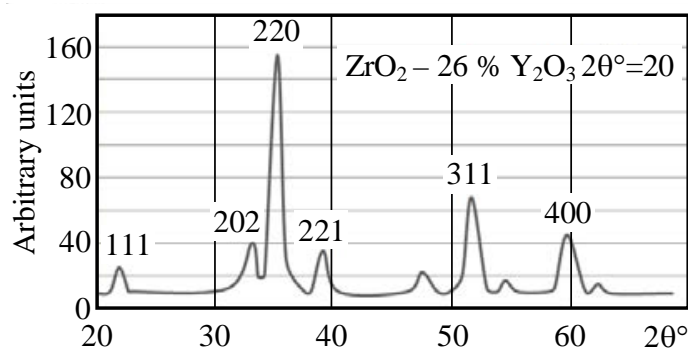

Fig. 1. Zirconium dioxide with an addition of $26 \% \mathrm{Y}_{2} \mathrm{O}_{3}$

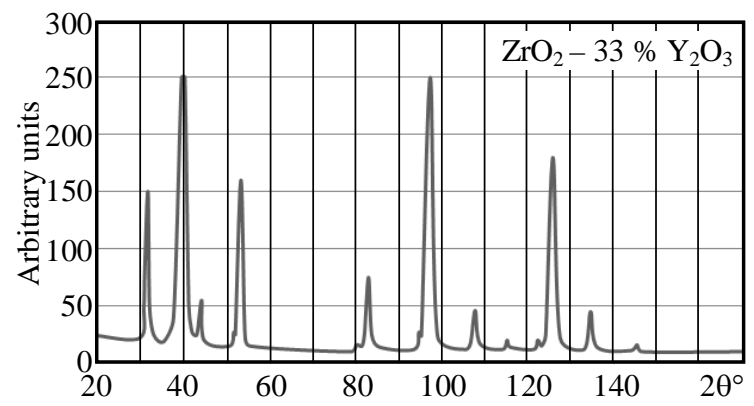

Fig. 3. Zirconium dioxide with an addition $33 \% \mathrm{Y}_{2} \mathrm{O}_{3}$

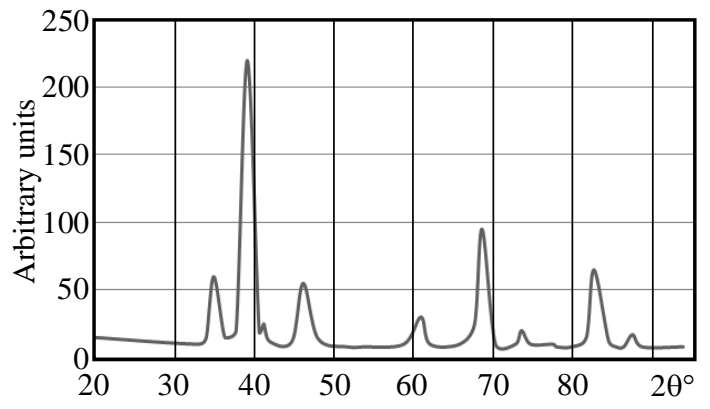

Fig. 2. Zirconium dioxide with an addition of $26 \% \mathrm{Y}_{2} \mathrm{O}_{3}$ and 5 hours annealing

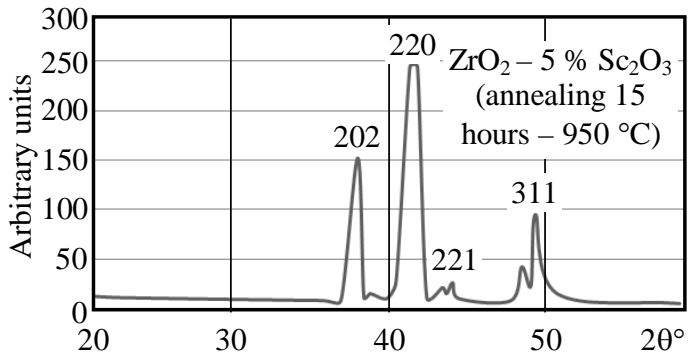

Fig. 4. Zirconium dioxide with an addition $5 \% \mathrm{Sc}_{2} \mathrm{O}_{3}$ and 15 hours annealing 


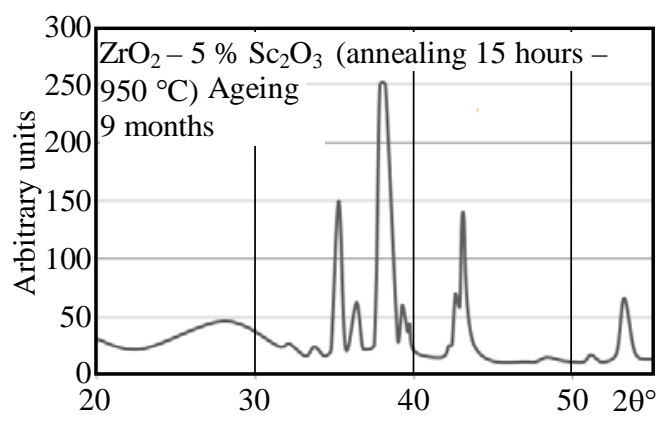

Fig. 5. Zirconium dioxide with an addition $5 \% \mathrm{SC}_{2} \mathrm{O}_{3}$ 15 hours annealing, aging during 9 months

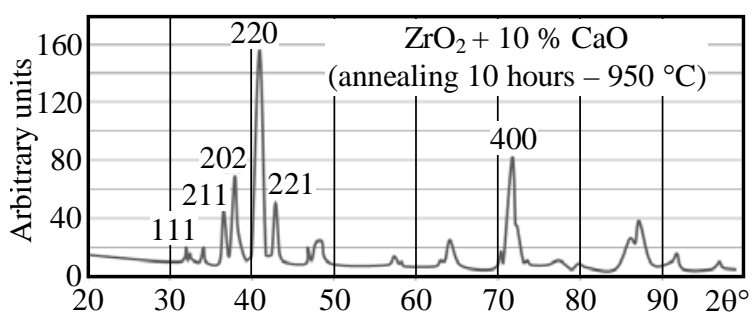

Fig. 6. Zirconium dioxide with an addition $10 \% \mathrm{CaO}$ and 10 hours annealing

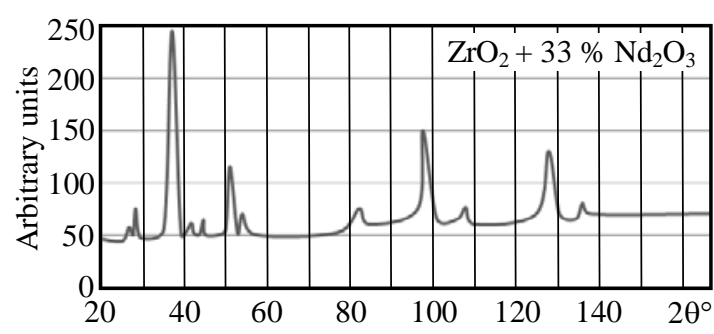

Fig. 7. Zirconium dioxide with an addition $33 \%$ $\mathrm{Nd}_{2} \mathrm{O}_{3}$

Discussion. It draws an attention to the redistribution of peaks intensity in all researched systems subjected to the annealing at temperature $1223 \mathrm{~K}$ that is close to the temperature of phase transformation from monoclinic structure into tetragonal $(1370 \mathrm{~K})$ in the pure zirconium dioxide. This can be evidence that ion-stabilizers streamlining at the special nodes of crystalline lattice of the matrix.

Particularly interesting are the results of studying of the system $\mathrm{ZrO}_{2}-\mathrm{Sc}_{2} \mathrm{O}_{3}$ presented on the Fig. 4 - Fig. 5. Atom of scandium is the only one, that has smaller radius than atom of zirconium, but stabilization of cubic phase also reveal. Roentgenograms shows that in this system cubic phase is not fully stabilized. This comes out from significant change of reflection peaks shape and intensity after ageing of the sample for almost 9 months. It is observed a return to the not fully stabilized cubic lattice.

We try to obtain any evidence of existence of pyrochlorum type structure in the system $\mathrm{ZrO}_{2}-$ $33 \% \mathrm{Y}_{2} \mathrm{O}_{3}$ and $\mathrm{ZrO}_{2}-33 \% \mathrm{Nd}_{2} \mathrm{O}_{3}$, but failed.

In all cases, a stabilizing annealing comes out in some intensity redistribution of roentgen reflections. However, it doesn't lead to the significant change of crystalline lattice parameters and as a result the specific volume of unit cell remains almost without changes. It means that solid solutions based on zirconium dioxide that have stabilized cubic phase can be used as protective coatings on the surface of construction materials.

Conclusions. An insertion of $\mathrm{Ca}, \mathrm{Y}, \mathrm{Nd}$, Sc ions into the lattice of $\mathrm{ZrO}_{2}$, stabilizes cubic type of solid solutions:

1. There are no phase transformations in the stabilized solid solutions based on $\mathrm{ZrO}_{2}$ that can lead to the change in specific volume and film cracking.

2. Structural studies of the systems based on $\mathrm{ZrO}_{2}$ make particular interest because $\mathrm{ZrO}_{2}$ is a chemi$\mathrm{cal}$ and structure homologue of the main uranium fuel $\mathrm{UO}_{2}$. However, radioactive and toxic peculiarities of $\mathrm{UO}_{2}$ make some difficulties of its research. Data obtained from the system based on $\mathrm{ZrO}_{2}$ can be useful when developing procedures to improve the fuel quality based on uranium dioxide $\left(\mathrm{UO}_{2}\right)$.

3. In view of the possibility of fretting corrosion, it is rational to apply protective coating on the surface of FR shell. This coating can be applied using a method of electron beam spraying of the layer from stabilized zirconium dioxide. Such modernization can provide the following results:

- stability of protective coating is maintained steady throughout all period of operation; 
- with a help of modernization it is possible to increase the duration of operation and so to increase the depth of burning.

4. Taking into account the possibility of vapor - zirconium reaction during emergencies, that is accompanied by significant hydrogen discharge, it is possible to apply another compounds such as siliceous carbide ( $\mathrm{SiC}$ ) as a protective coating for fuel rods shell.

\section{Література}

1. Finite element analysis of the tetragonal to monoclinic phase transformation during oxidation of zirconium alloys / Platt P., Frankel P., Gass M., Howels R., Preuss M. Journ. of Nuclear materials. 2014. 454 (1-3). 290-297.

2. Слісенко В.І., Зотєєв В.О., Василькевич О.А., Зотєєв О.Є., Кротенко В.В. Структура та фононні спектри нанорозмірних частинок твердих розчинів на основі діоксиду цирконію. Збірник доповідей 5-ї Міжнародної науково-практичної конференції «Безпека та ефективність атомної енергетики» 5-9 вересня 2016, м. Одеса ,Україна. 213-217.

3. Smith L., Mohammed T., Koh L., Reaney J. Life cycle assessment of functional material and devices: opportunities, challenges and current and future trends, Juornal Amer. Ceramic. Society. 2019. 102, № 12, 7037-7064.

4. Ghyngazov S. Influence of mechanical treatment on consolidation processes of ultradisperse powder of stabilized zirconium oxide. Inorganic Materials: Applied Research. 2018. 9, № 2. 343-346.

5. Sintering kinetics of $\mathrm{ZrO}_{2}$ nanopowders modified by grope IV elements / Lakusta M., Danilenko I., Volkova G., Loladze L., Burchovetsky V. Applied Ceramic Technology. 2019. 16, №4. 1481-1492.

6. Wei Liu, Lingling Jin, Shiwei Wang. The absorbtion and emission properties of highly transparent $\mathrm{ZrO}_{2}-$ doped $\mathrm{Yb}^{3+}: \mathrm{Y}_{2} \mathrm{O}_{3}$ ceramics. Journal Amer. Ceramic. Society. 2019. 102, №9. 5020-5024.

7. Gaglieri C., Alarcon R., de Godoi M. Thermal study of ZrO2 nanoparticles: effect of heating and cooling cycles on solid-solid transition. Thermochim. Acta. 2017. 653. 59-61.

\section{References}

1. Platt, P., Frankel, P., Gass, M., Howels, R., \& Preuss, M. (2014). Finite element analysis of the tetragonal to monoclinic phase transformation during oxidation of zirconium alloys. Journ. of Nuclear materials, 454 (1-3), 290-297.

2. Slisenko, V., Zoteev, V., Vasilkevitch, O., Zoteev, O., \& Krotenko, V. (2016). Structure and phonon spectra of nanosized particles of solid solutions based on zirconium dioxide. Proceedings of the 5th International Scientific and Practical Conference "Atomic Energy Safety and Efficiency" September, 5-9, 2016, Odessa, Ukraine, 213-217.

3. Smith, L., Mohammed, T., Koh, L., \& Reaney, J. (2019). Life cycle assessment of functional material and devices: opportunities, challenges and current and future trends. Juornal Amer. Ceramic. Society, 102, № 12, 7037-7064.

4. Ghyngazov, S. (2018). Influence of mechanical treatment on consolidation processes of ultradisperse powder of stabilized zirconium oxide. Inorganic Materials: Applied Research, 9, 2, 343-346.

5. Lakusta, M., Danilenko, I., Volkova, G., Loladze, L., \& Burchovetsky, V. (2019). Sintering kinetics of $\mathrm{ZrO}_{2}$ nanopowders modified by grope IV elements. Applied Ceramic Technology, 16, 4, 1481-1492.

6. Wei Liu, Lingling Jin, \& Shiwei Wang. (2019). The absorbtion and emission properties of highly transparent $\mathrm{ZrO}_{2}$ - doped $\mathrm{Yb}^{3+}: \mathrm{Y}_{2} \mathrm{O}_{3}$ ceramics. Journal Amer. Ceramic. Society, 102, 9, 5020-5024.

7. Gaglieri, C., Alarcon, R., de Godoi, M. (2017). Thermal study of ZrO2 nanoparticles: effect of heating and cooling cycles on solid-solid transition. Thermochim. Acta, 653, 59-61.

Чулкін Олег Олександрович; Chulkin Oleg, ORCID: http:// orcid.org/ 0000-0001-5048-4515

Кравченко Володимир Петрович; Kravchenko Volodymyr, ORCID: http:// orcid.org/0000-0002-7557-3327

Зотсєв Всеволод Олегович; Zotyeyev Vsevolod

Зотсєв Олег Свгенович; Zotyeyev Oleg, ORCID: http:// orcid.org/ 0000-0001-7114-4894 